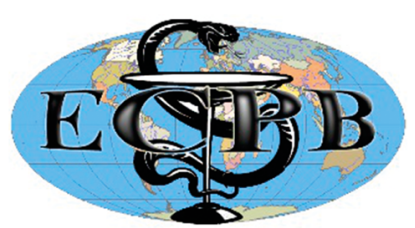

"ЕКСПЕРИМЕНТАЛЬНА ТА КЛІНІЧНА ФІЗІОЛОГІЯ І БІОХІМІЯ" "EXPERIMENTAL AND CLINICAL PHYSIOLOGY AND BIOCHEMISTRY" Науково-практичний журнал/Scientific-practical journal

Пам'ятні дати / Memorable dates ECPB 2019, 2(86): 77-81. https://doi.org/

М.Р. ГЖЕГОЦЬКИЙ, В.I. ФЕДОРЕНКО

\title{
БОРИС МИХАЙЛОВИЧ ШТАБСЬКИЙ (до 90-річчя від дня народження (1929-2017)
}

У червні 2019 р. виповнилося б 90 років від дня народження відолого вченого гігієніста $і$ токсиколога, талановитого педагога вищої школи, лауреата премї ілені Ю.С. Кагана Українського наукового товариства токсикологів, доктора медичних наук, профбесора Бориса Михайловича Штабського.

Борис Михайлович Штабський народився 24 червня 1929 р. у м. Вінниці в родині службовців. Дитячі роки минули в рідному місті. Трудове загартування розпочалося 313 років у евакогоспіталі № 3358, де виконував посильну для свого віку роботу. Працював на ремонтно-механічному заводі. У повоєнні роки родина переїхала до Львова.

1950 р. вступив на лікувальний фракультет до Львівського державного медичного інституту. По завершенню навчання та отриманню диплома 1956 р. був скерований на кафедру загальної гігієни, де здолав усі щаблі від старшого лаборанта кафедри до професора і завідувача кафедри. Становлення Б.М. Штабського як талановитого вченого відбувалося під керівництвом заслуженого діяча науки України проф. В.З. Мартинюка, який того часу очолював кафедру загальної гігієни, і члена-кореспондента ПАН та АМІІ України проф. Ю.С. Кагана (керівник відділу загальної токсикології та експериментальної патології УкрIІДІГІПТОКС, тепер ДП «Науковий центр превентивної токсикології, харчової та хімічної безпеки імені академіка Л.ІІ. Медведя МОЗ України»). Борис Михайлович вважав їх своїми вчителями, дослухався до їхньої думки і завдячував своїми науковими досягненнями.

Перші наукові дослідження розпочав на посаді старшого лаборанта. За рік у медичних журналах з'явилися перші наукові напрацювання з питань гігієни дітей і підлітків, що стосувалися гігієнічної ощінки навчального процесу в школах м. Львова. Активна й наполеглива робота стала підгрунтям обрання його на посаду асистента у 1957 р. Відтоді додалося обов'язків. Поряд із проведенням практичних занять продовжував наукові дослідження, зокрема, зі з'ясування причин виникнення дерматитів хімічної етіології та їх профілактики у шахтарів Львівсько-Волинського вугільного басейну. Саме цей напрям спонукав молодого науковця розпочати систематичні експериментальні дослідження у галузі профрілактичної токсикології. Наступні наукові праці тематично зв'язані з кандидатською дисертацією «Окись углерода как клеточный яд», яку Б.М. Штабський захистив 1965 р. Дослідження присвячені токсикології оксиду вуглецю і вивченню його впливу на протоплазму клітини ізольованих органів і організм загалом. Отримані результати засвідчили важливість глибокого вивчення механізмів дії шкідливих речовин і патогенезу отруєнь для розв'язання власне гігієнічних завдань. 1968 р. Борис Михайлович отримав звання доцента. Продовжив

(C) Гжегоцький M.P., Федоренко B.I., 2019 
наукові дослідження з проблеми кумуляції, які стали загальновизнаними і належать до видатних наукових досягнень. Проф. Б.М. Штабський розвинув принципово нові уявлення суті й методів вивчення кумулятивної дії хімічних речовин, визначені молекулярні механізми і кінетичні характеристики первинного кумулятивного ефекту, запропонував систему критеріїв і методів комплексної оцінки кумулятивних властивостей речовин, зокрема й за умов гострого досліду. Цій проблемі присвячена докторська дисертація Б.М. Штабського «Методические основы изучения кумуляции в токсиколого-гигиенических исследованиях», яку захистив 1975 р. Вчення про кумуляцію ксенобіотиків на сучасному етапі вагомо визначається науковими дослідженнями і працями профр. Б.М. Штабського. Запропоновані ним методичні рішення були представлені в офіційних методичних документах у 1976-1988 рр. широко використовувалися у наукових дослідженнях щодо гігієнічного нормування хімічних речовин у об'єктах довкілля.

У 1977 р. Б.М. Штабський перевівся на кафредру гігієни харчування 3 курсом гігієни дітей і підлітків, з 1979 р. працював на посаді профресора, 1980 р. отримав звання і диплом профресора, 1981 р. обраний завідувачем кафредри. З 1991 р. започаткував викладання профрілактичної токсикології для студентів, що згодом стало основою створення кафедри гігієни та профілактичної токсикології, яку й очолював до 2000 р. а потім до 2008 р. продовжував працювати на посаді профресора кафедри. 1996 р. на кафедрі започатковано курс гігієни фракультету післядипломної освіти. Упродовж 1977-1991 рр. був керівником ПДР робіт, які виконувалися на базі науково-дослідного сектору кафедри нормальної фрізіології. Напрям наукових досліджень стосувався експериментального обірунтування гігієнічних нормативів хімічних речовин, які впроваджувалися у виробництво з метою застосування в промисловості й сільському господарстві.

Узагальнюючи основні напрями наукових досліджень у гігієні та профрілактичній токсикології профр. Б.М. Штабського, наголосимо, що вони зв'язані передусім із розробленням фрундаментальних методологічних проблем вивчення токсичності й небезпечності шкідливих хімічних речовин $\mathrm{i}$ ïх гігієнічного нормування в об'єктах навколишнього середовища та харчових продуктах. Він побудував оригінальні концепції кумуляції, комбінованої дії, опрацював теорію і методологію системного регламентування ксенобіотиків у різних середовищах за звичайних і екстремальних умов, розробив прискорені методи обірунтування нормативів у об'єктах довкілля. Уперше ввів принципово нову залежність доза-статус на підставі діагностики передпатологічних станів у токсикологічному експерименті, розвинув методичні підходи до регламентації речовин шкірно-резорбтивної дії у воді водойм і вивчення процесів трансформації при обгрунтуванні нормативів ксенобіотиків у водному середовищі. Для підвищення інформативності експериментальних досліджень і надійності кількісних характеристик біологічної дії шкідливих речовин при їх гігієнічному нормуванні застосував математичний аналіз трикоординатних "доза-час-едект» i двокоординатних "дозаефект», «час-ефрект» і ізоефективної «доза-час» залежностей. Аналіз дозових залежностей проводив за умов гострого досліду та повторної дії шкідливих речовин з урахуванням реакцій у альтернативній та градуйованій формах. Для дослідження кількісних реакцій організму на основі залежності «дозаефект» опрацював метод імовірнісної оцінки ефективних, мінімально ефективних і максимально неефективних доз. Сфрормулював і застосував нові підходи до вирішення багаторівневого нормативного захисту гігієнічного забезпечення у повітрі робочої зони за показниками працездатності на основі дозових залежностей (рівень практичної індеферентності, безпечності та аварійності) для ліквідаторів хімічних катастроф.

Згодом упродовж 2011-2016 pр. профр. Б .М. Штабський опублікував серію нових праць, присвячених гігієнічному нормуванню ксенобіотиків, докладно визначивши за його словами «нові ідеї і старі проблеми», а також 
вченню про кумуляцію та його застосуванню у профілактичній токсикології. Зокрема, виклав власну позицію про кумуляцію, згідно з якою «кумуляція належить до найбільш спільних явищ, що спостерігаються за будь-яких форм хімічної агресії, окрім блискавичних летальних отруєнь». Кумуляція, за визначенням профр. Б.М. Штабського, це зміна токсичності ксенобіотиків у часі, й зокрема, максимально досяжне збільшення токсичності (посилення дії) у процесі гострого, підгострого (субхронічного), і хронічного (пожиттевого) впливу. При цьому зауважував, що визначення деяких критеріїв кумуляції може дезорієнтувати дослідників у оцінюванні кумулятивних властивостей і безпечних рівнів шкідливої речовини. Тому наголошував на потребі інтегративної (комплексної, кваліметричної, якісно порівняльної) оцінки кумуляції за сукупністю токсикодинамічних і токсикокінетичних критеріїв, беручи до уваги можливі характеристики швидкості старіння організму в горонтолого-токсикологічних дослідженнях.

З ім'ям проф. Б.М. Штабського пов'язано чимало нових ідей, присвячених опрацюванню фундаментальних методологічних проблем і методичних аспектів регламентації ксенобіотиків, важливих для різних галузей гігієни гігієни води, гігієни харчування, гігієни праці, гігієни дітей і підлітків. Він уперше проаналізував вітчизняну нормативну базу 90-х років минулого століття у порівняні з міжнародною практикою регламентування ксенобіотиків. Цей аналіз враховували під час опрацювання теорії і методології системного регламентування ксенобіотиків. Побудована єдина система гігієнічного нормування хімічних речовин впроваджена у практичну діяльніть - офіційно затверджені методичні вказівки "Обірунтування гігіенічних нормативів шкідливих хімічних речовин у різних середовищах на основі системного підходу» ( К., 2002). Методологія системного регламентування передбачає визначення закономірних співвідношень між гігієнічними нормативами хімічних речовин у різних середовищах за критеріями токсичності.

Профр. Б.М. Штабський розвинув новий напрям наукових досліджень ізетодичну схему гігієнічного нормування ксенобіотиків у харчових продуктах, яка увійшла до підручників з гігієни харчування. На основі розроблених методичних підходів обгрунтовано допустимі добові дози для свинщю, кадмію, ртуті, миш'яку, що надходять із добовим раціоном харчування. Він уперше запропонував знизити гранично допустиму концентрацію важких металів у харчових продуктах з метою безпеки харчування населення різного віку. За його керівництва вивчали фрактичне харчування, розроблено стандарти фізичного розвитку дітей дошкільного віку м. Львова. Він започаткував розвиток науково-практичного токсиколого-фрізіологічного напряму, дослідження ролі адаптації при розв'язанні завдань нормативного забезпечення хімічної безпеки працюючих і населення, розроблення адекватної методології доклінічної, індивідуальної і популяційної діагностики.

Наукові ідеї профр. Б.М. Штабського отримали розвиток у працях учнів. Під його керівництвом захищено 4 кандидатські й 3 докторські дисертації. Учитель щедро ділився зі своїми учнями науковими ідеями і думками, щиро радів їхнім успіхам і становленню, своїм оптимізмом, високою ерудицією, досвідом, професіоналізмом і нескінченним позитивом вселяв упевненість у досягненні мети.

Розроблені профр. Б .М. Штабським методичні та методологічні рішення і практичні рекомендації офіційно визнані на державному та міжнародному рівнях. Його науковий доробок становить понад 400 наукових праць, у т. ч. 8 монографій, 6 підручників і довідників, авторських свідоцтв, 12 офріційно затверджених методичних рекомендацій, у т. ч. на міжнародному рівні в межах ЮГІЕП/МРПТХВ, Комісії зі співпраці в галузі охорони здоров’я країн-членів РЕВ тощо, понад 50 розроблених гігієнічних нормативів ксенобіотиків. Зацікавленість науковими дослідженнями і публікаціями профр. Б.М. Штабського та його учнів виявляли не лише вітчизняні вчені, а й учені з різних країн, особливо після опублікованої низки праць у зарубіж- 
них виданнях у 90 роках минулого століття. 3-поміж виданих монографій у т. ч. «Токсикометрия химических веществ, загрязняющих окружающую среду» (М., 1986), «Химические загрязнители воздушной среды и работоспособность человека» (1985). «Ксенобіотики, гомеостаз і хімічна безпека людини " (Львів, 1999), «Профилактическая токсикология и прикладная фризиология: общность проблем и пути решения» (Львів, 2003), «Нариси профрілактичної медицини» (Львів, 2008). Иого наукові праці друкувалися у журналах і збірках праць міжнародних конференцій Великої Британії, США, Нідерландів, Польщі, Ізраїлю, Росії. Б.М. Штабський тісно співпрацював з відомими гігіеністами і токсикологами - проф. Ю.С. Каганом, проф. Е.М. Красовським, профр. Б.О. Кацнельсоном, проф. Л.О. Тіуновим, профр. Л.М. Шафрраном та ін.

Профр. Б. М. Штабський був таллановитим і висококваліфрікованим педагогом, досвідченим методистом. Його змістовні, цікаві, емоційні практичні заняття і лекції завжди супроводжувалися науковим підтвердженням. Він приділяв значну увагу удосконаленню навчально-методичної роботи на кафредрі, за його керівництва підготовлено низку методичних рекомендацій для студентів, збірники ситуаційних задач. За його ініціативою розроблено навчальну програму і впроваджено викладання профілактично і токсикології для студентів, складено навчальну програму з нутриціології як елективного курсу для студентів. Борису Михайловичу належить ідея викладання основ профрілактичної медицини при підготовці лікаря загальної практики, який має бути професійно підготовленим передусім як лікар-профілактик. За його керівництва на кафедрі розпочато післядипломне навчання інтернів та проведення курсів підвищення кваліфрікації лікарів-гігієністів. У ЛІІМУ імені Данила Галицького очолював профільну методичну комісію «Профілактична медицина». Він автор низки посібників і науково-методичних праць для студентів і лікарів, співавтор двох видань підручника «Гігієна харчування з основами нутриціології» (1999, 2007).

Упродовж багатьох років проф. Б.М. Штабський був членом секції «Гігіена води і санітарна охорона водойм», секції з обгрунтування ГДК пестицидів у повітрі робочої зони, проблемних комісій «Наукові основи гігієни навколишнього середовища», «Наукові основи гігієни харчування», експертом Постійної комісії з питань державних випробувань і державної регламентації пестицидів та агрохімікатів, двох комісій Комітету з питань гігієнічного нормування МОЗ України, членом правлінь Українських наукових товариств гігієністів і токсикологів, головою правління Львівського обласного наукового товариства токсикологів, членом редакційних рад журналів «Вопросы питания», «Современные проблемы токсикологии». Він був першим серед тих, хто отримав премію імені Ю.С. Кагана Українського наукового товариства токсикологів. Його нагороджено медаллю «За перемогу над Німеччиною», ювілейними медалями та почесними грамотами.

Життя профр. Б.М. Штабського було насичене творчими пошуками і здобутками, професійним талантом ученого, педагога, керівника, надзвичайною працьовитістю, почуттям обов'язку відповідальністю, інтелігентністю і доброзичливістю.

Борис Михайлович відійшов у вічність 12 квітня 2017 р. на 88-му році житТя.

Ім'я профресора Б.М. Штабського назавжди вписане до сторінок історії Львівського національного медичного університету імені Данила Галицького та історії української гігієнічної науки. Світлу пам'ять про видатного вченого і педагога, Вчителя, Людину щедрої і благородної душі, людяності, доброти і високої порядності назавжди збережуть у своїх серцях учні, колеги, послідовники й усі, хто знав його. 


\section{ДЖЕРЕЛА ІНФОРМАЦІЇ}

1 .Зіменковський БС, Гжегоцький $М Р$, Луцик ОД. Професори Львівського національного медичного університету імені Данила Галицького: 1784-2009. Львів : Наутілус; 2009. 472.

2. Історія розвитку та здобутки Львівської наукової гігієнічної школи / БС Зіменковський, MP Гжегоцький, ВI Федоренко, БА Пластунов. Гігієнічна наука та практика: сучасні реалії : матеріали XV з"їзду гігіеністів України (м. Львів, 20-21 верес. 2012 р.). Львів, 2012. 10-4.

3. Львівська наукова гігіенічна школа: історія розвитку та здобутки / БС Зіменковський, МР Гжегоцький, ВI Федоренко, БА Пластунов. Довкілля та здоров’я. 2013; 4: 68-74.

4. Гжегоиький MP, Федоренко ВI. Наукова діяльність доктора медичних наук, професора Бориса Михайловича Штабського (до 85-річчя 3 дня народження).

5. Гжегоиький M.P., Федоренко В.I. Обгрунтування гігіенічних нормативів ксенобіотиків у воді водойм під керівництвом професора Б.М. Штабського від 1977 р. до 1991 р.

6. Півстоліття пошуку і перемог (до 80-річчя від дня народження проф. Штабського Б.М. Довкілля і здоров'я. 2009; 4: 34. 